\title{
Penggunaan Surat Kuasa Membebankan Fidusia (SKMF) Di Bawah Tangan sebagai Dasar Pembuatan Akta Fidusia Ditinjau Dari Hukum Jaminan Di Indonesia
}

\author{
Mohamad Toha Dhukas \\ Magister Kenotariatan, Universitas Islam Indonesia
}

\begin{abstract}
Problems in this study, the first: whether the use SKMF under the hand as the basis for loading / fiduciary deed can be done, if the terms of the legal guarantee? Second, how is the legal effect of the fiduciary certificates have been obtained creditor, if at the time of loading / deed fidusianya, fueled by SKMF under the hand? The research is a normative juridical. The study concluded that, first, the use of SKMF under the hand as the basis for loading / fiduciary deed can not be justified under the national security law. Although UUJF not set, this does not mean the use of SKMF under the hand can be justified. Second, with the use of a power in the loading / fiduciary deed, then the validity of the result obtained from the loading / fiduciary deed, will depend (dependent) on the validity of proxies. So if creditors overburden / a deed of fiduciary through SKMF under the hand, it will bring consequences can not be obtained privileges as promised by law to creditors fiduciary certificate holder.
\end{abstract}

Keywords: power of attorney, deeds, fiduciary guarantees.

\begin{abstract}
Abstrak
Permasalahan dalam penelitian ini, pertama: apakah penggunaan SKMF di bawah tangan sebagai dasar pembebanan/pembuatan akta fidusia dapat dilakukan, jika ditinjau dari hukum jaminan ? Kedua, bagaimanakah akibat hukum terhadap sertifikat fidusia yang telah diperoleh kreditor, apabila pada saat pembebanan/pembuatan akta fidusianya di dasari dengan SKMF di bawah tangan ? Jenis penelitian ini adalah yuridis normative. Hasil penelitian menyimpulkan bahwa, pertama, penggunaan SKMF di bawah tangan sebagai dasar pembebanan/pembuatan akta fidusia tidak dapat dibenarkan menurut hukum jaminan nasional. Walapun UUJF tidak mengaturnya, hal ini bukan berarti penggunaan SKMF di bawah tangan dapat dibenarkan. Kedua, dengan digunakannya suatu kuasa dalam pembebanan/pembuatan akta fidusia, maka keabsahan terhadap akibat yang diperoleh dari pembebanan/pembuatan akta fidusia tersebut, akan bergantung (dependent) pada keabsahan kuasanya. Sehingga apabila kreditor membebani/membuat akta fidusia melalui SKMF di bawah tangan, maka akan membawa konsekuensi dapat tidak diperolehnya hak-hak istimewa sebagaimana yang telah dijanjikan oleh undang- undang kepada kreditor pemegang sertifikat fidusia.
\end{abstract}

Kata kunci: surat kuasa, akta, fidusia, jaminan. 


\section{Pendahuluan}

Hukum jaminan memiliki kaitan yang erat dengan bidang hukum benda dan lembaga keuangan, baik itu lembaga keuangan perbankan maupun lembaga keuangan non perbankan. Dalam kaitannya dengan lembaga keuangan ini terletak pada fungsi lembaga keuangan yaitu sebagai penghimpun dan penyalur dana masyarakat, yang salah satu usahanya adalah memberikan kredit. ${ }^{1}$

Pada asasnya tak ada hubungan hukum termasuk kredit yang tidak dijamin. ${ }^{2}$ Hal ini dapat dilihat dalam Pasal 1131 Kitab Undang undang Hukum Perdata (selanjutnya disebut KUHPerdata) dimana diletakan asas umum hak seorang kreditor kepada debitornya, yang mengatakan bahwa :

Segala kebendaan si berutang, baik yang bergerak maupun yang tak bergerak, baik yang sudah ada maupun yang baru akan ada dikemudian hari, menjadi tanggungan untuk segala perikatan perseorangan.”

Namun jaminan yang diberikan Pasal 1131 KUHPerdata diatas merupakan jaminan yang bersifat umum, jaminan umum sering dirasakan tidak aman, karena jaminan secara umum berlaku bagi semua kreditor, sehingga apabila kreditornya lebih dari satu dapat saja kekayaan debitor habis dan tidak mencukupi utang-utangnya. Oleh karenanya untuk lebih meyakinkan kreditor dan untuk menghindari kemungkinan seperti tersebut diatas, maka dalam pemberian kredit, kreditor perlu meminta jaminan yang diperjanjikan secara khusus oleh debitor disamping jaminan yang telah diberikan oleh pasal 1131 KUHPerdata.

Dengan adanya jaminan yang diperjanjikan secara khusus oleh debitor, akan memberikan kedudukan kreditor yang lebih baik, kedudukan lebih baik disini, adalah lebih baik dalam usahanya mendapatkan pemenuhan (pelunasan) piutangnya dibanding dengan para kreditor yang tidak mempunyai hak jaminan yang diperjanjikan secara khusus oleh debitor.

Secara yuridis dikenal dua macam bentuk jaminan yang dapat diminta untuk diperjanjikan secara khusus oleh debitor, yaitu jaminan perorangan dan jaminan kebendaan. Jaminan yang paling disukai oleh kreditor adalah jaminan kebendaan. Salah satu lembaga

\footnotetext{
${ }^{1}$ Tan Kamello, Hukum Jaminan Fidusia Suatu Kebutuhan Yang Di Dambakan, Cetakan Kedua (Bandung: PT. Alumni, 2014), hlm. 1

${ }^{2}$ J. Satrio, Parate Eksekusi Sebagai sarana Mengatasi Kredit Macet, (Bandung; PT. Citra Aditya Bhakti, 1993), hlm.3.
} 
jaminan kebendaan yang dikenal dalam hukum positif adalah fidusia. ${ }^{3}$ Keberadaan fidusia sudah dikenal oleh hukum kita sejak zaman penjajahan Belanda, dimana dahulu keberadaanya didasarkan pada yurisprudensi ${ }^{4}$ dan sekarang telah diatur dalam undangundang tersendiri.

Dengan telah diaturnya ketentuan jaminan fidusia dalam Undang-undang Nomor 42 Tahun 1999 tentang Jaminan Fidusia (yang selanjutnya disebut UUJF) diharapkan dapat memberikan kepastian dan menampung kesulitan-kesulitan yang dibutuhkan oleh praktek selama ini. Meskipun pada kenyataannya, tak semua masalah-masalah yang timbul dalam praktek dapat ditampung oleh UUJF, sehingga sesuatu yang dicita-citakan dalam UUJF selama ini belum dapat diwujudkan seutuhnya.

Salah satu masalah yang muncul dalam praktek saat ini adalah, maraknya penggunaan Surat Kuasa Membebankan Fidusia di bawah tangan dalam lingkungan lembaga keuangan, baik itu lembaga keuangan perbankan maupun non perbankan. Surat Kuasa Membebankan Fidusia (Selanjutnya disebut SKMF) adalah kuasa yang diberikan oleh debitor kepada kreditor untuk membebankan/membuat akta fidusia dihadapan notaris. Dengan adanya kuasa tersebut, kereditor dapat membebankan/membuat akta fidusia sewaktu-waktu tanpa perlu lagi bantuan dari debitor.

Pada dasarnya UUJF maupun peraturan pelaksanaanya tidak pernah mengenal maupun mengatur tentang SKMF. Menurut UUJF apabila kreditor ingin memperoleh hak jaminan fidusia atas benda yang dijaminkan debitor, maka setelah ditandatanganinya perjanjian kredit semestinya diikuti dengan pembebanan/ pembuatan akta fidusia ${ }^{5}$, yang selanjutnya atas dasar akta tersebut akan ditindak lanjuti dengan pendaftaran objek jaminan fidusia ke Kantor Pendaftaran Fidusia (KPF) guna memperoleh sertifikat jaminan fidusia yang memuat irah-irah "Demi Keadilan Berdasarkan Ke Tuhanan Yang Maha Esa" yang sifatnya mempunyai kekuatan eksekutorial, yaitu kekuatan yang sama dengan keputusan pengadilan yang telah memperoleh kekuatan hukum tetap.

${ }^{3}$ Tan Kamello, Op.cit, hlm. 2-3

${ }^{4}$ Belanda mengenal Fidusia lewat Yurisprudensi yang dikenal dengan Bierbrowerij Arrest tanggal 25 Januari 1929 dan di Indonesia dikenal melalui putusan Mahkamah Agung tanggal 18 Agustus 1932 dalam kasus Bataafsche Petroleum Maatschappij (BPM) vs Pedro Clignett.

${ }^{5}$ Menurut ketentuan Pasal 5 ayat 1 Undang-undang No.42 Tahun1999 tentang Jaminan fidusia menyebutkan bahwa Akta Fidusia wajib dibuat dengan akta notaris dan dalam bahasa Indonesia, yang selanjutnya dipertegas dalam penjelasannya yang menyebutkan bahwa dalam Akta Jaminan Fidusia selain mencantumkan hari dan tanggal, juga mencantumkan waktu (jam) pembuatan akta tersebut. Akta notaris adalah akta otentik yang dibuat oleh atau di hadapan notaris menurut bentuk dan tata cara yang ditetapkan dalam Undang-undang Jabatan notaris. 
Dengan munculnya praktek penggunaan SKMF di lingkungan lembaga keuangan saat ini, untuk memperoleh hak jaminan fidusia setelah ditandatanganinya perjanjian kredit, kreditor tidak langsung bersama sama debitor untuk membebani/membuat akta fidusia dihadapan notaris, melainkan antara kreditor dan debitor terlebih dahulu dibuat SKMF di bawah tangan, yang mana dalam penerapannya, setelah dibuatnya perjanjian kredit, kreditor akan menyodorkan SKMF dalam bentuk baku untuk ditandatangani debitor. Pokok isi SKMF tersebut adalah, debitor memberikan kuasa kepada kreditor dengan hak subtitusi untuk membuat akta fidusia atas benda yang dijaminkan debitor. Kuasa ini dibuat untuk tidak dapat dicabut lagi (onheroepolijk). Atas dasar telah dibuatnya kuasa tersebut, apabila dirasa perlu kreditor bertindak baik untuk diri sendiri maupun untuk dan atas nama debitor menghadap notaris untuk membebani/membuat akta fidusia yang selanjutnya ditindaklanjuti dengan pendaftaran objek jaminan fidusia guna memperoleh hak-hak istimewa sebagaimana telah dijanjikan oleh undang-undang.

Kemunculan penggunaan SKMF dalam praktek pembuatan akta fidusia sebenarnya diilhami dari pembuatan SKMH (Surat Kuasa Membebankan Hipotik) dan SKMHT (Surat Kuasa Membebankan Hak Tanggungan). Hal yang membedakan disini, di dalam Kitab Undang-undang Hukum Perdata (selanjutnya disebut KUHPerdata) dan Undang undang Nomor 04 Tahun 1996 tentang Hak Tanggungan (selanjutnya disebut UUHT) memang secara tegas telah mengatur dan memungkinkan pembebanan hipotik dan hak tanggungan melalui kuasa, dengan syarat-syarat dan bentuk yang telah ditetapkan. ${ }^{6}$ Sedangkan mengenai pembuatan SKMF sama sekali tak ada ketentuan menyinggung maupun pernah mengaturnya baik itu di dalam UUJF maupun peraturan pelaksanaannya.

\section{Rumusan Masalah}

Berdasarkan uraian dari latar belakang masalah di atas, maka dapat dirumuskan bahwa masalah yang akan dibahas dalam penelitian ini, pertama, apakah penggunaan SKMF di bawah tangan sebagai dasar pembebanan/pembuatan akta fidusia dapat dilakukan, jika ditinjau dari hukum jaminan ? Kedua, bagaimanakah akibat hukum terhadap sertifikat fidusia yang telah diperoleh kreditor, apabila pada saat pembebanan/pembuatan akta fidusianya di dasari dengan SKMF di bawah tangan?

\footnotetext{
${ }^{6}$ Pasal 1172 KUHPerdata Kusa memasang Hipotik wajib dubuat dalam bentuk otentik
} 


\section{Tujuan Penelitan}

Adapun tujuan penelitian ini, pertama untuk mengatahui penggunaan SKMF di bawah tangan sebagai dasar pembebanan/pembuatan akta fidusia dapat dilakukan, jika ditinjau dari hukum jaminan ? Kedua, untuk mengatahui akibat hukum terhadap sertifikat fidusia yang telah diperoleh kreditor, apabila pada saat pembebanan/pembuatan akta fidusianya di dasari dengan SKMF di bawah tangan.

\section{Metode Penelitian}

Metode penelitian yang digunakan dalam penulisan ini adalah metode peneletian yuridis normatif, ${ }^{7}$ yaitu dengan meneliti sumber-sumber bacaan yang relevan dengan tema penelitian, meliputi penelitian terhadap asas-asas hukum, sumber-sumber hukum, peraturan perundang-undangan yang bersifat teoritis ilmiah serta dapat menganalisa permasalahan yang dibahas. Pilihan penelitian hukum secara normatif digunakan dalam penulisan ini di karenakan permasalahan yang diangkat adalah mengenai kekosongan norma, di mana peraturan tidak mengatur sama sekali mengenai pembebanan jaminan fidusia melalui SKMF dan akibat hukum terhadap sertifikat fidusia yang diperoleh karenanya.

\section{Hasil Penelitian dan Pembahasan}

\section{Penggunaan Surat Kuasa Membebankan Fidusia Untuk Membuat Akta Jaminan Fidusia}

Digunakannya suatu kuasa adalah dimaksudkan agar penerima kuasa menjadi berwenang melakukan perbuatan hukum untuk dan atas nama pemberi kuasa. Kuasa dapat diberikan melalui perbuatan hukum sepihak, ${ }^{8}$ atau perbuatan hukum dalam bentuk perjanjian seperti lastgeving. Kuasa yang diberikan secara sepihak hanya menimbulkan wewenang bagi penerima kuasa, namun tidak menimbulkan kewajiban bagi penerima kuasa untuk melaksanakan kuasa itu. Sedangkan apabila kuasa itu diberikan melalui perbuatan

\footnotetext{
${ }^{7}$ Penelitian hukum normatif adalah penelitian hukum yang dilakukan dengan cara meneliti bahan pustaka atau data sekunder, lihat Soerjono Soekanto dan Sri Mamudji, Penelitian Hukum Normatif Suatu Tinjauan Singkat, (Jakarta: Raja Grafindo Persada, 1995), hlm. 13.

${ }^{8}$ Kuasa (Volmacht) yang diberikan melalui perbuatan hukum sepihak disebut machtiging yaitu pernyataan kehendak oleh orang yang diwakili yang tertuju kepada pemberian "macht" (kuasa). Hartono Soerjopratiknjo,Op.Cit., hlm. 63.
} 
hukum perjanjian seperti lastgeving, maka kuasa itu menimbulkan kewajiban bagi penerima kuasa untuk melaksanakan kuasa. ${ }^{9}$

Dalam bahasa Indonesia biasanya lastgeving, mactiging maupun volmacht sering diterjamahkan dalam satu arti kata yaitu "kuasa" padahal ketiganya memiliki makna yang berbeda. Kuasa (volmacht) merupakan keadaan hukum, sedangkan lastgeving dan machtiging merupakan perbuatan hukum yang dapat melahirkan kuasa (volmacht). ${ }^{10}$

Pemberian kuasa merupakan suatu perbuatan hukum, oleh karena itu pemberian kuasa hanya dapat dilakukan oleh orang yang cakap hukum (handelings bekwamheid). Pemberian kuasa berakibat pemberi kuasa dapat dipertanggung jawabkan oleh tindakan orang lain sebagai penerima kuasa dan tindakan penerima kuasa akan dianggap sebagai tindakan pemberi kuasa.

Sebagai suatu perbuatan hukum pada prinsipnya pemberian kuasa tidak terikat suatu bentuk tertentu. Sepanjang tidak ditentukan lain oleh undang-undang, ia dapat diberikan secara lisan maupun tertulis. Menurut pasal 1793 KUHPerdata pemberian kuasa dapat diberikan dan diterima dalam bentuk $:^{11}$

\section{a. Akta_Otentik}

Pemberian kuasa yang diberikan dengan akta otentik adalah pemberian kuasa yang dilakukan dihadapan pejabat umum yang berwenang dan dalam bentuk akta yang telah ditentukan oleh undang undang. Mengenai pengertian dari akta otentik itu sendiri dapat kita temukan di dalam pasal 1868 KUHPerdata yang memberikan batasan secara unsur tentang apa yang dimaksud dengan akta otentik yaitu : ${ }^{12}$ 1) Akta itu harus dibuat oleh (door) atau dihadapan (ten overstaan) seorang pejabat umum; 2) Akta itu harus dibuat dalam bentuk yang ditentukan oleh undang-undang; 3) Pejabat umum oleh-atau dihadapan siapa akta itu dibuat harus mempunyai wewenang untuk membuat akta tersebut.

Selain daripada itu, yang perlu diketahui dari akta otentik adalah, bahwa akta otentik merupakan akta yang istimewa. Keistimewaan dari akta otentik terletak pada kesempurnaan kekuatan pembuktian yang dimilikinya, dalam artian, akta otentik sudah tidak memerlukan

\footnotetext{
${ }^{9}$ Rachmad Setiawan, Op.cit., hlm. 20.

${ }^{10}$ Hartono Soerjopratiknjo, Op.Cit., hlm.35

${ }^{11}$ Guse Prayudi, Seluk Beluk Perjanjian, (Yogyakarta:Pustaka Pena,2007), hlm.52

${ }^{12}$ Habib Adjie, Kebatalan dan Pembatalan Akta Notaris, Cetakan I, (Bandung:RefikaAditama, 2011),
} hlm. 5-6 
suatu penambahan atau dukungan alat bukti lain untuk membuktikan kebenarannya. Sehingga apa yang tertulis di dalam akta otentik harus dianggap benar adanya.

\section{b. Akta Di bawah Tangan}

Pemberian kuasa dengan akta di bawah tangan adalah kuasa yang diberikan secara tertulis oleh pemberi kuasa, baik itu dengan atau tanpa campur tangan pejabat. Suatu akta di bawah tangan, tidak terikat oleh bentuk formal tertentu, dan dapat dibuat oleh setiap subjek hukum yang berkepentingan untuk membuatnya. Dilihat dari pembuktiannya terdapat tata urutan kekuatan pembuktian yang dimiliki akta di bawah tangan $:^{13}$

1) Akta di bawah tangan yang dilegalisasi

Kekuatan pembuktian dari akta di bawah tangan yang dilegalisasi belum/tidak sesempurna akta notariil, namun ada jaminan dari pejabat umum (notaris) bahwa tanda tangan yang tertera di akta di bawah tangan tersebut benar-benar tanda tangan dari orang/pihak yang disebutkan dalam akta tersebut.

2) Akta di bawah tangan yang diwarmerking

kekuatan pembuktiannya berada di bawah akta di bawah tangan yang dilegalisasi, karena tidak ada jaminan dari pejabat umum bahwa cap ibu jari /tanda tangan yang diterakan /tercantum di akta di bawah tangan tersebut adalah benar tanda tangan dari yang bersangkutan.

3) Akta di bawah tangan tanpa campur tangan pejabat

Kekuatan pembuktiannya berada di bawah akta di bawah tangan yang dilegalisasi dan di warmerking. Namun dalam hal akta di bawah tangan tersebut diakui oleh oleh pihak yang bersangkutan, maka akta tersebut memiliki kekuatan pembuktian yang kuat.

\section{c. Surat Biasa.}

Pemberian kuasa yang diberikan dengan surat biasa adalah kuasa yang diberikan melalui surat tidak atas segel/tanpa materai yang dinyatakan si pemberi kuasa dengan si penerima kuasa untuk melakukan suatu perbuatan hukum.

\section{d. Secara Lisan.}

Pemberian kuasa yang diberikan secara lisan adalah kuasa yang diberikan oleh pemberi kuasa kepada penerima secara tidak tertulis.

\section{e. Secara Diam-diam.}

${ }^{13}$ Mulyoto, Perjanjian (Tehnik, Cara Membuat, Dan Hukum Perjanjian Yang Harus Dikuasai), (Yogyakarta: Cakrawala Media, 2012), hlm.11-12. 
Pemberian kuasa yang diberikan secara diam-diam adalah kuasa yang pemberiannya maupun penerimaannya dapat disimpulkan dari pelaksanaan kuasa. Ketentuan pemberian kuasa dengan diam-diam ini telah disebutkan dalam Pasal 1793 ayat (2) KUHPerdata.

Adapun demikian terdapat kuasa yang terikat pada suatu bentuk tertentu. Ini terlihat pada kuasa untuk memberikan hipotik harus dibuat dengan suatu akta otentik, ${ }^{14}$ kuasa untuk mencoret pembukuan hipotik harus dengan akta otentik, ${ }^{15}$ kuasa untuk membebankan hak tanggungan harus otentik, ${ }^{16}$ kuasa untuk menerima hibah harus dengan akta otentik, ${ }^{17}$ kuasa untuk membuat akta pendirian PT harus secara tertulis, ${ }^{18}$ kuasa untuk menghadiri RUPS harus secara tertulis, ${ }^{19}$ dan kuasa untuk mewakili kreditor dalam acara kepailitan dan penundaan pembayaran harus secara tertulis. ${ }^{20}$ Pelanggaran atas ketentuan undang-undang tentang bentuk kuasa yang telah ditetapkan tersebut berakibat pada kebatalan kuasanya. ${ }^{21}$

Dalam hal dimana suatu perbuatan hukum mensyaratkan bentuk tertentu, apakah kuasa untuk melakukan tindakan hukum tersebut juga harus mengikuti bentuk tertentu itu ?. Menurut Van Brakel dan Klaassen-Eggens-Luyten, bentuk kuasanya juga harus mengikuti bentuk tertentu itu, dengan alasan bahwa ketentuan bentuk mengenai perbuatan hukum dimaksudkan untuk perlindungan bagi orang yang hendak melakukan perbuatan hukum tersebut. Sehingga apabila orang yang bertindak tersebut ingin memberi kuasa kepada orang lain, maka adalah wajar jika kuasa tersebut juga terikat dengan bentuk yang berlaku bagi tindakan hukumnya. Berdasarkan pendapat tersebut Van Der griten tidak menyetujuinya. Menurutnya maksud undang-undang tidak selalu dapat diketahui dan ketentuan bentuk yang melindungi tindakan hukum itu tidak akan kehilangan arti apabila kuasanya dibebaskan dari ketentuan bentuk tersebut. ${ }^{22}$

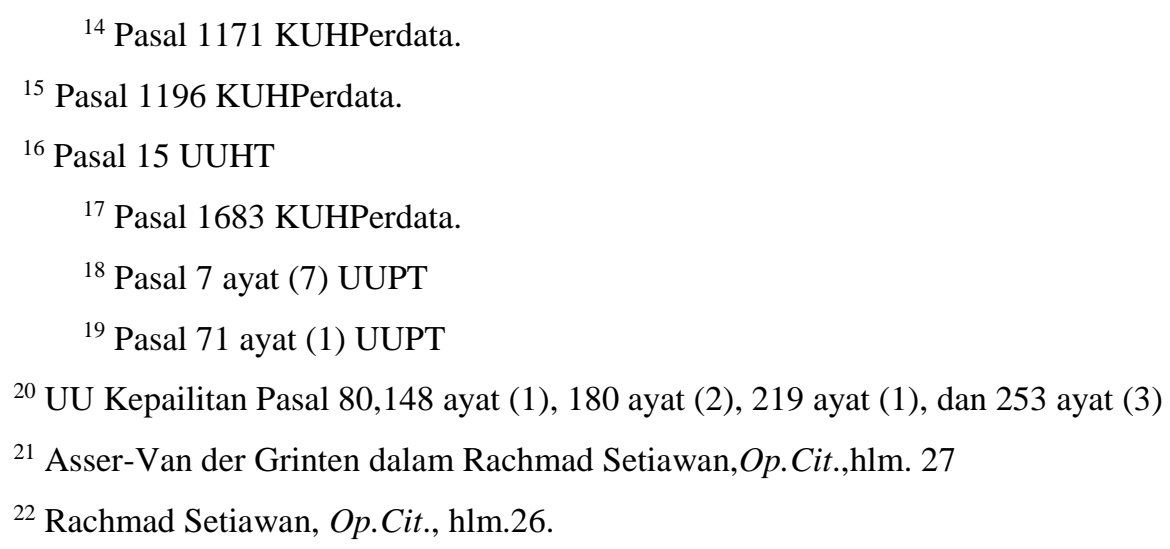

${ }^{14}$ Pasal 1171 KUHPerdata.

${ }^{15}$ Pasal 1196 KUHPerdata.

${ }^{16}$ Pasal 15 UUHT

${ }^{17}$ Pasal 1683 KUHPerdata.

${ }^{18}$ Pasal 7 ayat (7) UUPT

${ }^{19}$ Pasal 71 ayat (1) UUPT

${ }^{20}$ UU Kepailitan Pasal 80,148 ayat (1), 180 ayat (2), 219 ayat (1), dan 253 ayat (3)

${ }^{21}$ Asser-Van der Grinten dalam Rachmad Setiawan,Op.Cit.,hlm. 27

${ }^{22}$ Rachmad Setiawan, Op.Cit., hlm.26. 
Dalam perkembangannya, sepanjang tidak ditentukan lain oleh undang-undang pada prinsipnya, pemberian kuasa merupakan perbuatan hukum yang bebas bentuk. Hoge Raad pada tanggal 25 Februari 1987 pernah menghadapi pertanyaan apakah suatu kuasa untuk melakukan hibah dimana untuk penghibahan barang tidak bergerak diperlukan akta notariil juga berlaku untuk kuasanya ?. Hoge Raad menjawabnya dengan kata "tidak". 23

Dalam penulisan ini sebagaimana telah disampaikan dalam latar belakang, juga terdapat persoalan yang kurang lebih sama sebagaimana telah diuraikan diatas, yaitu mengenai keberadaan dan bentuk SMKF yang digunakan sebagai dasar pembebanan/pembuatan akta fidusia. Yang mana dalam UUJF hanya mengatur bahwa bentuk perbuatan hukum dalam wujud pembebanan/pembuatan akta fidusia wajib dibuat dengan akta otetik, namun UUJF maupun peraturan pelaksanaannya sama sekali tidak mengatur dapat atau tidaknya SKMF dibuat dan bagaimana bentuknya.

SKMF adalah kuasa yang diberikan oleh debitor kepada kreditor untuk membebankan/membuat akta fidusia dihadapan notaris. Sehingga dengan adanya kuasa tersebut, kereditor dapat membebankan/membuat akta fidusia tanpa perlu lagi bantuan dari debitor.

Kemunculan praktek pembuatan SKMF dilingkungan lembaga keuangan saat ini sebenarnya adalah inisiatif dari kreditor yang ingin menghadirkan suatu keadaan dimana kreditor dapat sewaktu-waktu mewakili debitor untuk membebani/membuat akta fidusia dihadapan notaris, yang mana setelah dibuatnya akta fidusia tersebut, oleh kreditor akan ditindaklanjuti dengan pendaftaran objek jaminan fidusia di Kantor Pendaftaran Fidusia (KPF) guna memperoleh sertfikat fidusia yang sifatnya mempunyai kekuatan eksekutorial. Atas dasar telah diperolehnya sertifikat fidusia tersebut, maka apabila debitor wanprestai kreditor dapat langsung mengeksekusi objek jaminan fidusia yang dijaminkan debitor tanpa harus melalui proses pengadilan yang panjang dan melelahkan.

Dalam penerapannya, penggunaan SKMF dilingkungan lembaga keuangan saat ini, memang disinyalir kreditor yang telah memegang SKMF jarang untuk segera merealisir secara nyata pembebanan fidusianya. Kreditor masih merasa aman selama belum terdapat indikasi debitor kesulitan membayar angsuran atau wanprestasi.

Menanggapi persoalan tersebut, jika dilihat dari fungsinya memang fidusia diberikan untuk kepentingan kreditor dan karenanya diberikan bentuk perlindungan serta hak kepadanya. Secara teori apabila diakui bahwa fidusia itu hak, maka kita akan berada dalam

\footnotetext{
${ }^{23}$ Ibid., hlm. 28 .
} 
wilayah partij autonomie yaitu kebebasan bagi individu untuk mau menggunakan haknya atau tidak. Oleh karena itu, apabila kreditor pemegang SKMF tidak merealisir secara nyata pembebanan fidusianya, adalah terserah bagi kreditor yang bersangkutan untuk mau menggunakannya atau tidak, karena dengan tidak dibebaninya secara nyata objek jaminan fidusia akan membawa resiko sendiri bagi kreditor yang akan kehilangan kesempatannya untuk menjadi kreditor yang distimewakan sebagaimana yang telah dijanjikan oleh undangundang. Namun yang patut untuk dipertimbangkan disini adalah, bahwa pelaksanaan suatu hak tidaklah sama dengan menyalahgunakan suatu hak. Seseorang memang bebas untuk menggunakan atau tidak menggunakan haknya, akan tetapi jika dengan berbuat atau tinggal diam merupakan suatu penyalahgunaan hak, maka yang demikian itu sudah tentu tidak dapat dibenarkan.

Dilihat dari format SKMFyang diperoleh penulis, ${ }^{24}$ dapat diketahui bahwa SKMF tersebut dibuat di bawah tangan dan dituangkan dalam bentuk perjanjian, sehingga dapat disimpulkan bahwa SKMF tersebut berbentuk lastgeving. Ketentuan mengenai lastgeving secara jelas telah diatur dalam Buku III Bab XVI mulai dari pasal 1792 sampai dengan pasal 1819 KUHPerdata, ${ }^{25}$ sedangkan ketentuan mengenai dapat atau tidaknya dan bagaimana bentuk seharusnya SKMF dibuat, UUJF maupun peraturan pelaksanannya sama sekali tidak mengaturnya.

Di dalam UUJF hanya mengatur bahwa pembebanan/pembuatan akta fidusia wajib dibuat dengan akta otentik. ${ }^{26}$ Namun tidak pernah melarang atau mengatur pembebanan/pembuatan akta fidusia dilakukan melalui kuasa. Dengan adanya kekosongan hukum dalam UUJF inilah yang telah menyebabkan praktek mengadopsi ketentuan lastgeving dalam Buku III KUHPerdata untuk memenuhi inisiatifnya dalam pembuatan SKMF. Sehingga praktek berpendapat bahwa prinsip pemberian kuasa itu bebas bentuk dan dapat dilakukan untuk semua perbuatan hukum, ${ }^{27}$ dapat dijadikan dasar pembenar dalam pembuatan SKMF di bawah tangan. Adanya asas umum dalam hukum perdata, dimana selama tidak diatur maka itu boleh/dapat dilakukan juga telah mendukung pendapat

${ }^{24}$ Contoh Surat Kuasa Membebankan terlampir dalam tesis ini

${ }^{25}$ Herlien Budiono,.....Perdata Dibidang Kenotariatan, Buku I, Op.Cit.,hlm.53.

${ }^{26}$ Pasal 5 ayat (1) UUJF

27 Pada prinsipnya hampir semua tindakan hukum dapat dikuasakan kepada orang lain untuk melakukannya, kecuali sesuatu yang erat hubungannya dengan pribadi seseorang, misalnya, membuat surat wasiat/testament dan pengakuan anak 
paraktek dalam hal pembuatan SKMF dibawah tangan. Bahkan doktrin juga mengajarkan apabila suatu perbuatan hukum diwajibkan bentuk tertentu, bentuk kuasanya tetap bebas sepanjang undang-undang untuk kuasa itu tidak menentukan lain. ${ }^{28}$

Berdasarkan pertimbangan-pertimbangan tersebut, kiranya logis apabila praktek berpendapat bahwa penggunaan SKMF di bawah tangan dapat dilakukan dalam pembebanan/pembuatan akta fidusia, mengingat tidak ada satu ketentuan pun dalam UUJF yang melarang mengenai pembuatan SKMF di bawah tangan. Namun sebelum membenarkan atau mengikuti pendapat praktek diatas, patut untuk dipertimbangkann bahwa jaminan fidusia adalah bagian dari jaminan kebendaan yang merupakan sub sistem dari hukum benda yang meletakan asas tertutup dan memaksa (dwingendrecht). ${ }^{29} \mathrm{Hal}$ ini, tentu sangat bertolak belakang dengan lastgeving yang merupakan sub sistem dalam hukum kontrak yang meletakan asas terbuka dan pelengkap (aanvullendrecht). ${ }^{30}$ Sehingga semestinya, ketentuan lastgeving tidak dapat diadopsi begitu saja untuk mengisi ketiadaan pengaturan dalam sistem hukum benda. ${ }^{31}$ Prinsip bahwa ketentuan Buku III KUHPerdata tidak dapat diterapkan begitu saja dalam sistem hukum benda ini juga dapat dilihat pada keberadaan perjanjian kebendaan. Dimana ketentuan perjanjian obligatoir dalam Buku III KUHPerdata tidak semua berlaku/dapat digunakan dalam perjanjian kebendaan. ${ }^{32}$

\footnotetext{
${ }^{28}$ Asser Van der Grinten dalam J Satrio, Hukum Jaminan Hak Jaminan Kebendaan Tanggungan Buku I, (Bandung :PT Citra Aditya Bhakti,1998), hlm 168. Lihat Juga Rachmad Setiawan, Op.Cit., hlm.28.

${ }^{29}$ Hukum benda mempunyai sifat tertutup maksudnya ialah bahwa hak-hak benda hanya dapat diatur dengan undang-undang. Selain itu hukum benda mengandung sifat memaksa, maksudnya ialah bahwa ketentuan tentang hukum benda wajib dipatuhi dan tak dapat disimpangi. Mariam darus Badrulzaman, Sistem Hukum Benda Nasional, Op.Cit., hlm.4.
}

${ }^{30}$ Ketentuan dalam buku III KUHPerdata bersifat menambah atau mengatur atau melengkapi, dengan sifat yang demikian memiliki konsekuensi bahwa pihak pihak yang membuat perjanjian memiliki kebebasan untuk menyimpangi ketentuan-ketentuan yang terdapat dalam buku III tersebut. Buku III KUHPerdata juga menganut sifat terbuka yang bermakna orang bebas mengadakan perjanjian jenis baru selain yang dikenal/diatur dalam Buku III tersebut. Lihat Ridwan Khairandy, Hukum Kontrak Indonesia Dalam Perspektif Perbandingan, Bagian Pertama,(Yogyakarta:UII Press, 2013), hlm. 16-17.

31 Antara sistem hukum yang berbeda sering terdapat perbedaan-perbedaan. Ketentuan yang diketemukan dalam sistem yang satu tidak selalu dapat diterapkan begitu saja ke dalam sistem yang lain. Lihat Sudikno metrokusumo, Penemuan Hukum Sebuah Pengantar, Edisi revisi, (Yogyakarta:Cahaya Atma Pustaka, 2014), hlm.26

32 Kata perjanjian dalam perjanjian kebendaan, hanya dimaksudkan untuk menunjukan bahwa perjanjian kebendaan didasarkan atas kata sepakat. Jangan disalah artikan bahwa perjanjian kebendaan termasuk perjanjian dalam Buku III KUHPerdata. Perjanjian kebendaan merupakan perjanjian yang mengubah, mengalihkan maupun menimbulkan hak kebendaan. Selain itu perjanjian kebendan tidak menimbulkan perikatan-perikatan seperti perjanjian obligatoir. Sehingga disini ketentuan perjanjian dalam Buku III KUHPerdata tidak berlaku terhadap perjanjian kebendaan. Lihat Van Brakel dan Pitlo dalam J. satrio, Hukum Perikatan, Perikatan yang lahir dari Perjanjian Buku I, Cetakan II, (Bandung :PT Citra Aditya Bhakti,2001), hlm.57-58. 
Sebelum pembahasan lebih jauh, berikut juga penulis sampaikan pendapat mengenai keberadaan SKMF di bawah ini. yang menyatakan bahwa $:^{33}$

"apabila salah satu pihak ingin diwakili dalam pembuatan akta Jaminan Fidusia (Pembebanan Fidusia), maka pihak tersebut dapat membuat surat kuasa. Surat kuasa ini tidak harus dibuat dalam bentuk akta notariil, akan tetapi sebaiknya dilegalisasi oleh notaris. Dilegalisasi di sini artinya, penandatanganan surat kuasa tersebut dilakukan di hadapan notaris. Jadi, bentuknya bukan akta notaris, akan tetapi ada notaris yang menyaksikan penandatanganan surat kuasa tersebut."

Pendapat tersebut diatas, dengan jelas menyatakan bahwa perbuatan hukum dalam wujud penggunaan kuasa di bawah tangan dapat diterapkan dalam pembebanan/pembuatan akta fidusia, namun sebaiknya kuasa tersebut dilegalisasi. Pertimbangan diperlukan legalisasi dalam pembuatan kuasa dimaksudkan untuk menjamin kebenaran tanda tangan para pihak dalam kuasa di bawah tangan tersebut, sehingga apabila terdapat perselisihan, maka dapat dibuktikan bahwa para pihak yang dinyatakan di dalam kuasa di bawah tangan itu memang benar-benar telah menandatangani kuasa tersebut.

Menyimak dari pendapat di atas, dapat diketahui bahwa pendapat tersebut masih tak jauh berbeda dengan pandangan praktek dalam lingkungan lembaga keuangan yang menekankan pada asas bahwa selama tidak ada ketentuan yang mengaturnya, maka ketentuan lastgeving dalam Buku III KUHPerdata dapat diterapkan untuk pembuatan SKMF. Yang membedakan disini hanyalah terdapat saran sebaiknya SKMF tersebut dilegalisasi. Seandainya dilegalisasipun apa dasarnya bahwa SKMF yang telah dilegalisasi dapat diterima dalam sistem hukum jaminan kebendaan?.

Dengan dilegalisasinya suatu kuasa hanya akan menjadikan tambahan kekuatan pembuktian terhadap kuasa di bawah tangan. Hal itu bukan berarti bahwa SKMF yang telah dilegalisasi dapat digunakan sebagai dasar pembebanan/pembuatan akta fidusia. Jika hanya mengacu pada asas bahwa selama tidak dilarang itu boleh dan mengadopsi ketentuan lastgeving dalam Buku III KUHPerdata sebagai dasar pembenar, apakah nantinya juga akan dibenarkan jika kuasa untuk membebankan jaminan fidusia dilakukan dengan lisan atau diam-diam...?

Dalam hal tidak adanya ketentuan yang mengatur mengenai penggunaan SKMF dalam pembebanan/pembuatan akta fidusia bukan berarti serta merta dapat diterapkan bahwa sesuatu yang tidak diatur itu boleh, akan tetapi harus dilihat secara kasuistis. Seperti

\footnotetext{
${ }^{33} \mathrm{http}: / /$ www.hukumonline.com/klinik/detail/lt4c6cdcb7c88c7/surat-kuasa-fidusia-di-bawah-tangan
} 
yang diketahui, bahwa kemampuan pembuat undang undang itu terbatas, adakalanya pembuat Undang-undang tidak sempat mengatur suatu perbuatan dalam undang undang tapi mengaturnya lebih lanjut dalam peraturan perundang undangan lain, adakalanya perbuatan yang belum diatur oleh pembuat undang undang itu belum terpikirkan oleh pembuat undang-undang, karena pada saat itu belum dirasakan mendesak untuk diatur atau tidak diduga akan terjadi kemudian. ${ }^{34}$ Oleh karena itu, untuk mengetahui apakah dapat atau tidaknya digunakan SKMF sebagai dasar pembebanan/pembuatan akta fidusia maka perlu untuk menemukan hukumnya, seseorang tidak dapat begitu saja mengatakan boleh, atau menetapkan bentuk tertentu hanya dengan dasar tidak ada ketentuan yang mengaturnya.

Dalam hal terjadi kekosongan hukum, ilmu hukum telah menyediakan beberapa metode yang dapat digunakan untuk menemukan hukum dalam keadaan mana undangundang tidak mengaturnya yaitu, antara lain : ${ }^{35}$

a. Argumentum Per Analogian (analogi)

Apabila peraturan perundang-undangan terlalu sempit ruang lingkupnya, maka akan diperluas dengan metode argumentum per analogian. Dengan metode analogi ini maka kekosongan hukum akan diisi ketentuan yang berlaku pada peristiwa yang serupa, sejenis atau keadaan dimana undang-undang memperlakukan sama. (contoh : Jual beli menurut Pasal 1576 KUHPerdata tidak akan memutuskan hubungan sewa menyewa. Dalam hibah, tukar menukar dan sebagainya tidak mengatur secara khusus mengenai hal tersebut. Maka dengan metode analogi ketentuan dalam Pasal 1576 KUHPerdata dapat ditafsirkan secara luas untuk berlaku pada setiap peralihan hak milik, sehingga disini ketentuan dalam Pasal 1576 KUHPerdata juga berlaku terhadap hibah dan tukar menukar ). ${ }^{36}$

\section{b. Argumentum a Contrario}

Dalam hal undang-undang tidak mengatur secara khusus, akan tetapi kebalikan dari peristiwa tersebut diatur oleh undang undang. Cara menemukan hukumnya ialah dengan pertimbangan bahwa apabila undang undang menetapkan hal-hal tertentu untuk peristiwa tertentu, maka peraturan itu terbatas pada peristiwa tertentu itu dan untuk peristiwa diluarnya berlaku kebalikannya. (misalnya : Tidak ada pasal-pasal dalam KUHPerdata yang menjelaskan mengenai apa yang dimaksud "sebab yang halal" pada Pasal 1320 KUHPerdata. Namun Pasal 1337 KUHPerdata mengatur tentang "sebab yang terlarang"

\footnotetext{
${ }^{34}$ Sudikno metrokusumo, Penemuan Hukum Sebuah Pengantar, Edisi revisi, (Yogyakarta:Cahaya Atma Pustaka, 2014), hlm.84.

${ }^{35}$ Ibid., hlm. 86.

36 Ibid., hlm.88
} 
yaitu sebab yang bertentangan dengan undang-undang, kesusilaan dan ketertiban umum. Dengan menafsirkan Pasal 1337 KUHPerdata secara a contrario, maka dapat diketahui bahwa sebab yang halal adalah sebab yang tidak bertentangan sengan undang-undang kesusilaan, dan ketertiban umum). ${ }^{37}$

c. Penyempitan Hukum (Rechtverfijning)

Kadang peraturan perundang-unadangan itu ruang lingkupnya terlalu umum atau luas, maka perlu dipersempit untuk dapat diterapkan terhadap peristiwa konkret tertentu. Dengan penyempitan hukum dibentukalah pengecualian-pengecualian atau penyimpangan-penyimpangan baru dari peraturan peraturan yang bersifat umum. Peraturan yang bersifat umum diterapkan terhadap peristiwa atau hubungan hukum yang khusus dengan penjelasan atau konstruksi dengan memberi cirri - ciri. (contoh : Asas itikad baik (goude trouw) dalam Pasal 1338 KUHPerdata merupakan norma kabur yang luas dan umum sifatnya, dimana dalam pasal tersebut dikatakan bahwa "Perjanjian harus dilaksanakan dengan itikad baik" karena terlalu luas dan umum sifatnya maka agar dapat diterapkan secara konkret harus dipersempit dengan disesuaikan dengan peristiwa konkret yang bersangkutan. HR dalam putusannya tanggal 9 februari 1023 NJ 1923,676 mempersempit itikad baik dalam Pasal 1338 KUHPerdata dengan rumusan Menurut syarat-syarat kelayakan dan kepatutan. Jadi pelaksanaan perjanjian harus diuji dengan norma objektif yang tidak tertulis). ${ }^{38}$

Namun untuk menemukan hukum atas sesuatu yang tidak diatur dalam undangundang, haruslah mengingat akan sistem hukumnya. ${ }^{39}$ Karena dengan melihat hukum sebagai sistem akan membantu untuk menemukan dan mengisi kekosongan hukum dengan sederhana.

Untuk membicarakan Hukum sebagai suatu sistem, tentu tak bisa lepas dari pembicaraan tentang sistem itu sendiri, karena bagaimanapun juga hukum sebagai suatu sistem, pasti akan tunduk pada batasan dan ciri-ciri sistem juga. Oleh karena itu, sebelumnya diperlukan pemahaman tentang pengertian sistem secara umum, sistem hukum dan sistem hukum jaminan.

\footnotetext{
${ }^{37}$ Ibid., hlm. 91

${ }^{38}$ Ibid., hlm.93

${ }^{39} \mathrm{Ibid} ., 85$.
} 


\section{Lxx Renaissance No. 2 VOL. 1 JULI 2016: 234 - 257}

Kata sistem mempunyai dua pengertian yang penting untuk dikenali, sekalipun dalam pembicaraan secara umum keduanya sering dipakai secara tercampur begitu saja. Pertama pengertian sistem sebagai satuan (entitas) yang memiliki tatanan tertentu dan kedua pengertian sistem sebagai metode atau tata cara. ${ }^{40}$

Kedua pengertian sistem tersebut dapat dilihat dari apa yang dikatakan oleh William A.Schrode dan Voich yang mengatakan :

The system has two important connotations which are implicit, if not explicit, in almost any discussion of system. The first is the notion of system as an entity or thing which has a particular order or structural arrangement of is parts.The second is the notion of system as a plan, method,device, or procedure for accomplisingsomething.As we shall see,these two notions are not markedly different,since order structur is fundamental to each. ${ }^{41}$

Oleh karena itu, pengertian sistem yang dijadikan acuan kerangka analisis jaminan fidusia adalah sistem sebagai entitas, memiliki tatanan tertentu yang menunjukan suatu struktur yang tersusun atas elemen-elemen atau bagian-bagian yang berkaitan satu dengan yang lainnya untuk mencapai tujuan.

Secara sederhana sistem diartikan sebagai a set of element, such as people, things, an concepts, which, are related to archieve a mutual goal, (artinya sekumpulan unsur, seperti manusia, benda-benda, konsep-konsep, yang berhubungan untuk mencapai tujuan bersama). ${ }^{42}$

Mahadi mengemukakan bahwa sistem adalah suatu totalitas yang tersusun atas sejumlah komponen-komponen yang saling berhubungan, dan sama-sama mewujudkan suatu keutuhan untuk mencapai tujuan tertentu diantara komponen itu ada yang mempunyai fungsi terhadap yang lain. ${ }^{43}$

R.Subekti mengatakan bahwa suatu sistem adalah suatu susunan atau catatan yang teratur, suatu keseluruhan yang terdiri atas bagian-bagian yang berkaitan satu sama lain tersusun menurut suatu rencana atau pola hasil dari suatu pemikiran untuk mencapai suatu tujuan. $^{44}$

\footnotetext{
${ }^{40}$ Satjipto Rahardjo, Ilmu Hukum, (Bandung, PT.Citra Aditya Bhakti, 2014), hlm.48.

${ }^{41}$ Tan Kamello, Op.Cit, hlm.146

${ }^{42}$ Robert G. Murdick dan Joel E. Ross dalam Tan Kamello, Ibid.

${ }^{43}$ Mahadi dalam Mariam Darus Badrulzaman, Sistem Hukum Benda Nasional, Op.Cit., hlm.2.

${ }^{44}$ R. Subekti dalam Tan Kamello, Op.Cit.,hlm.147
} 
Berdasarkan beberapa pengertian sistem diatas, dapat disimpulkan bahwa penekanan arti sistem terletak kepada keterkaitan antara unsur-unsur atau bagian- bagiannya yang saling bekerja sama untuk mencapai tujuan.

Selain makna sistem tersebut diatas, perlu juga diketahui pengertian dari sistem hukum yaitu keseluruhan tata tertib hukum yang dibangun diatas fondasi berupa asas (prinsip). Asas-asas ini satu sama lain saling berkaitan, merupakan kesatuan, bersifat terpadu dan harmonis. ${ }^{45}$

Menurut Sudikno Mertokusumo sistem hukum merupakan satu kesatuan yang utuh yang terdiri dari bagian-bagian atau unsur-unsur yang saling berkaitan satu sama lain dan berkerja sama untuk mencapai satu tujuan kesatuan tersebut. ${ }^{46}$ Selanjutnya dijelaskan bahwa sistem hukum merupakan satu kesatuan yang hakiki dan terbagi bagi dalam bagianbagian, di dalam mana setiap masalah atau persoalan menemukan jawaban atau penyelesaiannya. ${ }^{47}$

Dilihat dari pendapat-pendapat diatas, maka dapat disimpulkan bahwa suatu sistem hukum adalah peraturan hukum (norma hukum), asas-asas hukum yang menjadi fundamen, dan pengertian-pengertian hukum. Unsur sistem hukum itu di bangun diatas tertib hukum, sehingga terdapat keharmonisan dan dapat dihindarkan tumpang tindih diantara masingmasing unsur tersebut. Jika terdapat konflik antara unsur-unsur sistem hukum, solusinya adalah terletak dalam sistem hukum itu sendiri.

Dengan mengkontruksikan hukum sebagai sistem, maka ciri sistem hukum itu di dalamnya pasti terdapat sub sistem. Dalam sub sistem terbagi lagi dalam beberapa bagian sub-sub sistem hukum. Demikian seterusnya sub-sub sistem terbagi ke dalam sub-sub sistem yang lebih kecil, yang secara keseluruhannya memiliki hubungan satu dengan yang lainnya secara utuh dan bersifat harmonis, tidak terdapat benturan dalam rangka mencapai tujuannya.

Berdasarkan uraian diatas, dapat dijelaskan bahwa sistem hukum jaminan merupakan bagian/sub sistem hukum benda, sedangkan sistem hukum benda adalah bagian/sub sistem dari sistem hukum perdata. Demikian pula sistem hukum perdata merupakan sub sistem hukum nasional.

\footnotetext{
${ }^{45}$ Mariam Darus Badrulzaman, Sistem Hukum benda Nasional, Op.Cit.,, hlm.2.

${ }^{46}$ Sudikno Mertokusumo, Mengenal Hukum Suatu Pengantar, Cetakan III (Yogykarta:Liberty, 2007), hlm.122

${ }^{47}$ Ibid., hlm. 123
} 
Sistem hukum jaminan terbagi dalam 2 (dua) bagian yakni sistem hukum jaminan perorangan dan sistem hukum jaminan kebendaan. Sistem hukum jaminan perorangan yang obyeknya adalah perorangan merupakan sub sistem hukum dari hukum kontrak yang mengandung asas pribadi (personal right). Sedangkan sistem hukum jaminan kebendaan yang objeknya adalah benda merupakan sub sistem dari hukum benda yang mengandung asas kebendaan (real right). ${ }^{48}$

Berdasarkan sistematika hukum jaminan diatas, dapat diketahui bahwa hukum jaminan telah meletakan jaminan kebendaan sebagai bagian/sub sistem dari hukum benda. Sistem hukum jaminan kebendaan yang terdiri dari jaminan gadai (pand), hipotik, hak tanggungan dan jaminan fidusia.

Dengan telah mengetahui hukum jaminan kebendaan merupakan suatu sistem hukum, maka dapat dipahami bahwa undang-undang yang diciptakan sebagai bagian dari hukum jaminan kebendaan meliputi gadai (pand), hipotik, hak tanggungan dan jaminan fidusia bukanlah sekedar kumpulan peraturan-peraturan/norma-norma yang berdiri sendiri. Melainkan masing-masing peraturan tersebut memiliki arti penting dalam kaitannya dengan peraturan-peraturan hukum jaminan kebendaan secara keseluruhan, yang dibangun diatas asas-asas tertib hukum jaminan untuk mencapai suatu tujuan. Oleh karena itu, untuk menyelesaikan persoalan dapat atau tidak digunakannya SKMF dalam pembebanan/pembuatan akta fidusia, dapat diselesaikan dengan menggunakan metode penemuan hukum Argumentum Per Analogian (analogi), yaitu dengan menganalogikan fidusia dengan jaminan kebendaan lainnya dalam suatu sistem hukum jaminan kebendaan.

Melihat pada hipotik dan hak tanggungan dapat diketahui bahwa apabila memang diperlukan, penggunaan kuasa dapat diterapkan dalam pembebanan objek jaminan (Pasal 1171 KUHPerdata dan Pasal 15 UUHT). Oleh karena itu, penggunaan SKMF untuk pembebanan/pembuatan akta fidusia juga dapat dibenarkan menurut sistem hukum jaminan, tentu dengan syarat bahwa bentuknya juga harus mengikuti bentuk kuasa yang dikenal dan memang diatur dalam hukum jaminan kebendaan, yaitu harus dituangkan dalam bentuk otentik. Sehingga penyimpangan akan bentuk kuasanya, akan mengakibatkan kebatalan terhadap SKMF tersebut. Ketentuan lastgeving dalam Buku III KUHPerdata tidak semua dapat diberlakukan/digunakan untuk pemberian kuasa dalam sistem hukum jaminan kebendaan. Penggunaan kata kuasa dalam hukum jaminan kebendaan hanya dimaksudkan untuk menunjukan bahwa dalam kuasa tersebut terdapat kewenangan. Hal ini tidak berarti

\footnotetext{
${ }^{48}$ Mariam Darus Badrulzaman , Aneka Hukum Bisnis, (Bandung: Alumni,1994),hlm.79-80.
} 
bahwa kuasa dalam hukum jaminan kebendaan adalah kuasa yang termasuk dalam dalam Buku III KUHPerdata.

\section{Akibat hukum penggunaan skmf di bawah tangan Terhadap sertifikat fidusia yang dihasilkan}

Dengan telah diperolehnya sertifikat fidusia oleh kreditor, maka kreditor telah memiliki bukti otentik untuk diakui sebagai kreditor yang memperoleh hak-hak istimewa sebagaimana telah dijanjikan oleh undang-undang. Dengan demikian, apakah semua kreditor pemegang sertifikat fidusia dapat dinyatakan sebagai kreditor yang mempunyai hak-hak istimewa sebagaimana dijanjikan undang-undang ?. Untuk menjawab hal tersebut secara pasti, tentu harus dilihat sebab-sebab apa saja yang telah dilalui oleh kreditor hingga memperoleh serifikat fidusia. Karena secara teori suatu faktor penyebab akan sangat berperan untuk menentukan suatu akibat. Oleh karena itu, sebelum menentukan bagaimana akibat hukum atas sertifikat fidusia yang diperoleh kreditor melalui SKMF di bawah tangan, sebaiknya ditinjau terlebih dahulu bagaimana proses perolehan sertifikat fidusia, yang dianjurkan oleh undang-undang maupun tahap-tahap perolehan sertifikat fidusia melalui SKMF di bawah tangan.

Secara yuridis ada beberapa fase yang harus dilalui agar kreditor dapat memperoleh sertifikat fidusia, yaitu:

\section{a. Dibuatnya perjanjian pokok/perjanjian kredit}

Dalam fase ini antara debitor dan kreditor diadakan perjanjian, dimana ditentukan bahwa debitor meminjam uang dengan jumlah tertentu dengan janji akan mengembalikan dalam waktu yang telah ditentukan/disepakati.

\section{b. Pembuatan Akta Fidusia}

Untuk menjamin pelaksanaan prestasi dari debitor atas perjanjian pokok, maka setelah ditandatanganinya perjanjian pokok/kredit, kreditor dan debitor wajib membuat akta jaminan fidusia. Menurut Pasal 5 angka (1) UUJF ditetapkan bahwa pembebanan/pembuatan akta fidusia wajib dibuat dengan akta notaris. ${ }^{49}$ dalam bahasa Indonesia. Selanjutnya dipertegas dalam penjelasannya yang menyebutkan bahwa dalam

\footnotetext{
${ }^{49}$ Akta notaris adalah akta otentik yang dibuat oleh atau di hadapan notaris menurut bentuk dan tata cara yang ditetapkan dalam undang-undang Jabatan notaries (Pasal 1 UUJN)
} 
Akta Jaminan Fidusia selain mencantumkan hari dan tanggal, juga harus mencantumkan waktu (jam) pembuatan akta tersebut.

Dalam akta jaminan fidusia sekurang-kurangnya memuat mengenai:

1) Identitas para pihak yang meliputi nama lengkap, agama, tempat tinggal atau kedudukan, tanggal lahir, jenis kelamin, status perkawinan, dan pekerjaan.

2) Data perjanjian pokok yang dijamin fidusia, yaitu mengenai macam perjanjian, dan utang yang dijamin dengan fidusia.

3) Uraian mengenai benda yang menjadi obyek Jaminan Fidusia.

Uraian mengenai benda yang menjadi obyek Jaminan Fidusia cukup dilakukan dengan mengidentifikasi benda tersebut, dan dijeIaskan mengenai surat bukti kepemilikannya. Dalam hal benda yang menjadi obyek jaminan fidusa merupakan benda dalam persediaan (inventory) yang selalu berubah-ubah dan tidak tetap, seperti stok bahan baku, barang jadi, maka akta Jaminan Fidusia dicantumkan uraian mengenai jenis, merek, kualitas dan benda tersebut.

4) Nilai penjaminan.

5) NiIai benda yang menjadi obyek Jaminan Fidusia.

\section{c. Pendaftaran Objek Jaminan Fidusia.}

Setelah dibuatnya akta fidusia maka objek jaminan fidusia tersebut wajib didaftarkan. Pendaftaran jaminan fidusia ditujukan kepada Kantor Pendaftaran Fidusia (KPF) yang merupakan bagian dari lingkungan Kementerian Hukum dan Hak Asasi Manusia. Adapun tujuan dari pendaftaran objek fidusia tersebut adalah untuk memberikan kepastian kepada kreditor mengenai benda yang telah dibebani jaminan fidusia, dan untuk memenuhi asas publisitas sehingga hak-hak terhadap objek jaminan fidusia dapat ditujukan kepada pihak ketiga. Permohonan pendaftaran dilakukan oleh kreditor penerima fidusia, kuasa atau wakilnya dengan melampirkan dokumen pernyataan pendaftaran Jaminan Fidusia, yang meliputi:
a. Identitas para pihak;
b. Tanggal, nomor akta Jaminan Fidusia, nama dan tempat kedudukan notaris yang membuat akta Jaminan Fidusia;
c. Data perjanjian pokok yang dijamin fidusia;
d. Uraian mengenai benda yang menjadi objek Jaminan Fidusia;
e. Nilai penjaminan, dan
f. Nilai benda yang menjadi obyek Jaminan Fidusia 
Sebagai kelanjutan daripada pendaftaran jaminan fidusia, maka oleh Kantor Pendaftaran Fidusia (KPF) dikeluarkan sertifikat jaminan fidusia pada tanggal yang sama dengan tanggal penerimaan permohonan pendaftaran, yang tentunya dimaksudkan sebagai bukti pendaftaran jaminan fidusia.

Sertifikat Jaminan Fidusia ini sebenarnya merupakan salinan dari Buku Daftar Fidusia yang memuat catatan tentang hal-hal yang sama dengan data dan keterangan yang ada pada saat pernyataan pendaftaran. Adapun ciri istimewanya adalah mengandung irahirah "Demi Keadilan Berdasarkan Ketuhanan Yang Maha Esa" yang mempuyai kekuatan eksekutorial, sama seperti dengan putusan pengadilan yang telah mempunyai kekuatan hukum tetap. Pencantuman irah-irah sebagaimana telah diberikan oleh undang-undang membawa konsekuensi, bahwa kreditor pemegang serifikat fidusia memiliki kewenangan eksekusi atas objek jaminan fidusia diluar campur tangan pengadilan apabila debitor wanprestasi. Dengan begitu besarnya kekuatan yang telah diberikan oleh UUJF, maka dapat diketahui bahwa kreditor yang telah memegang sertifikat fidusia memiliki kedudukan yang istimewa dimata undang-undang.

Dalam hal pembebanan jaminan fidusia melalui SKMF. Kreditor juga melalui tahapan-tahapan sebagaimana telah diuraikan diatas, namun disini terdapat suatu perbedaan yang mendasar, yaitu setelah dibuatnya perjanjian pokok tidak segera ditindak lanjuti untuk dibuat akta fidusia dihadapan notaris, melainkan oleh kreditor terlebih dahulu dibuat SKMF di bawah tangan, yang mana kuasa tersebut akan digunakan sebagai dasar dalam pembebanan/pembuatan akta fidusia.

Adapun untuk lebih jelasnya tahap pembebanan fidusia yang dilakukan melalui SKMF di bawah tangan dapat diuraikan sebagai berikut :

\section{a. Pembuatan Perjanjian pokok/kredit}

Dalam tahap ini tetap sama, yaitu dibuatnya perjanjian pokok yang berupa perjanjian kredit antara kreditor dan debitor.

\section{b. Pembuatan Surat Kuasa Membebankan Fidusia di Bawah Tangan}

Setelah dibuatnya perjanjian pokok, dalam fase ini kreditor akan meminta debitor untuk menandatangani SKMF. Yang pokok isinya debitor memberi kuasa kepada kreditor bertindak untuk dan atas namanya dalam hal pembuatan akta fidusia dihadapan notaris.

\section{c. Pembuatan Akta Fidusia}


Dalam fase pembuatan akta fidusia dihadapan notaris ini, kreditor bertindak sebagai 2 kualitas, yaitu bertindak untuk dan atas nama debitor sekaligus dirinya sendiri. Jika tidak menggunakan SKMF sebagai dasar untuk membebani/membuat akta fidusia, maka dalam tahap ini kreditor dan debitor bersama sama membuat akta fidusia dihadapan notaris. (Pasal 5 angka (1) UUJF).

\section{d. Pendaftaran Objek Jaminan Fidusia}

Selanjutnya atas dasar telah dibuatnya akta fidusia dihadapan notaris, kreditor akan menindak lanjuti pendaftaran objek fidusia di Kantor Pendaftaran Fidusia (KPF) dan memperoleh sertifikat fidusia.

Tetap dapat diperolehnya sertifikat fidusia meskipun pembebanan/pembuatan akta fidusianya dilakukan melalui SKMF di bawah tangan ini sebenarnya juga didukung oleh faktor pemberlakuan pendaftaran fidusia melalui sistem elektronik (online system). Ketentuan ini dapat dilihat pada Peraturan Menteri Hukum dan Hak Asasi Manusia Republik Indonesia Nomor 09 tahun 2013 tentang Pemberlakuan Pendaftaran Jaminan Fidusia Secara Elektronik, Peraturan Menteri Hukum dan Hak Asasi Manusia Republik Indonesia Nomor 08 tahun 2013 tentang Pendelegasian Penandatanganan Sertifikat Jaminan Fidusia Secara Elektronik dan Peraturan Menteri Hukum dan Hak Asasi Manusia Republik Indonesia Nomor 10 tahun 2013 tentang Tata Cara Pendaftaran Jaminan Fidusia Secara Elektronik.

Dengan diberlakukannya ketentuan-ketentuan tersebut, maka pendaftaran fidusia yang dulunya dilakukan secara manual di Kantor Pendaftaran Fidusia (KPF) telah beralih dengan menggunakan sistem pendaftaran jaminan fidusia secara online. Menurut Pasal 3 Peraturan Mentri Hukum dan Hak Asasi Manusia Nomor 9 Tahun 2013, menyatakan bahwa "Pendaftaran jaminan fidusia secara elektronik sebagaimana dimaksud dalam Pasal 2 dapat dilakukan melalui kios pelayanan pendaftaran jaminan fidusia secara eletronik diseluruh kantor pendaftaran fidusia". Kios pelayanan pendaftaran jaminan fidusia yang dimaksud tidak terdapat penjelasannya pada peraturan menteri tersebut.Selanjutnya pengertian kantor pendaftaran fidusia terdapat pada Pasal 1 ayat (5) Peraturan Menteri Nomor 10 Tahun 2013 menyatakan bahwa "kantor pendaftaran fidusia adalah kantor yang menerima permohonan pendaftaran jaminan fidusia secara elektronik". Pada pengertian ini pun tidak jelas kantor mana yang menerima permohonan pendaftaran jaminan fidusia secara elektronik.

Pada prakteknya pendaftaran jaminan fidusia secara elektronik atau online dilakukan di kantor notaris, karena hanya notaris yang memiliki username dan password untuk dapat mengakses menu layanan website www.ahu.go.id . Sehingga dengan adanya kewenangan 
akses yang dimilikinya tersebut, notaris akan melakukan pendaftaran jaminan fidusia secara online dengan menginput data sesuai dengan akta pembebanan yang dibuatnya, untuk selanjutnya notaris sendiri jugalah yang akan mencetak sertifikat fidusia yang mengandung irah-irah "Demi Keadilan Berdasarkan Ketuhanan Yang Maha Esa".

Dengan pemberlakuan pendaftaran fidusia melalui sistem elektronik (online system) tersebut, dapat diketahui bahwa proses pelaksanaan pendaftaran objek jaminan fidusia saat ini menjadi lebih mudah dan cepat, karena dapat diakses secara online melalui satu pintu yaitu notaris. Oleh karena itu, notaris yang berpandangan bahwa penggunaan SKMF di bawah tangan dapat diterapkan dalam pembebanan/pembuatan akta fidusia, tentu akan tetap memproses pendaftaran fidusia sampai kreditor memperoleh sertifikat fidusia. Sehingga dapat dikatakan bahwa notaris juga berperan terhadap keberadaan SKMF di bawah tangan.

Dengan tetap diperolehnya sertifikat fidusia oleh kreditor yang melakukan pembebanan/pembuatan akta fidusia melalui SKMF di bawah tangan, telah membawa anggapan pada kreditor penerima fidusia bahwa ia tetap merasa aman dan dilindungi hakhaknya sebagai kreditor yang istimewa dimata undang-undang. Karena toh apabila debitor wanprestasi ia tetap dapat mengeksekusi secara langsung objek fidusia yang dijaminkan debitor dengan menunjukan sertifikat jaminan fidusia yang telah diperolehnya dari pendaftran secara online melalui notaris.

Dengan demikian, apakah dapat dikatakan bahwa kreditor yang menggunakan SKMF di bawah tangan sebagai dasar pembebanan/pembuatan akta fidusia tetap mempunyai hak-hak istimewa yang diberikan undang-undang?. Secara teori tentu tidaklah demikian adanya. Sebagaimana telah disampaikan di atas bahwa faktor penyebab akan sangat berperan untuk menentukan suatu akibat. Dilihat secara administratif memang kreditor telah memenuhi syarat untuk memperoleh sertifikat fidusia yaitu dengan dibuatnya akta fidusia notariil (pasal 5 ayat (1) UUJF dan didaftarkanya objek jaminan fiusia (Pasal 5 ayat (1) jo. Pasal 11 UUJF), namun melihat dari perolehannya disini, terdapat suatu faktor penyebab yang tidak dapat dihilangkan yaitu digunakannya SKMF di bawah tangan sebagai dasar pembebanan/pembuatan akta fidusia. Sehingga hak- hak yang timbul mapun diperoleh kreditor dari pembebanan/pembuatan akta fidusia berdasarkan SKMF tersebut akan bergantung (dependent) pada keabsahan SKMF yang telah dibuat sebelumnya. Meskipun disini kreditor telah memperoleh sertifikat fidusia.

\section{Penutup}


Berdasarkan uraian dan pembahasan tersebut di atas maka dapat disimpulkan sebagai berikut: pertama, penggunaan SKMF di bawah tangan sebagai dasar pembebanan/pembuatan akta fidusia tidak dapat dibenarkan menurut hukum jaminan nasional. Walapun UUJF tidak mengaturnya, hal ini bukan berarti penggunaan SKMF di bawah tangan dapat dibenarkan. Secara sistemik hukum jaminan telah meletakan fidusia sebagai bagian dari sistem hukum jaminan kebendaan yang menganut asas tertutup dan memaksa (dwingendrecht). Oleh karena itu, ketiadaan pengaturan mengenai SKMF dalam UUJF tidak dapat begitu saja diisi oleh ketentuan lastgeving dalam Buku III KUHPerdata. Melainkan secara sistemik harusnya digunakan ketentuan hukum jaminan kebendaan yang lain untuk melengkapinya. UUJF bukanlah sekedar kumpulan peraturan-peraturan/normanorma yang berdiri sendiri. Melainkan memiliki arti penting dalam kaitannya dengan peraturan-peraturan hukum jaminan kebendaan secara keseluruhan yang dibangun diatas asas-asas tertib hukum untuk membentuk suatu kesatuan dalam sistem hukum jaminan kebendaan. Kedua, dengan digunakannya suatu kuasa dalam pembebanan/pembuatan akta fidusia, maka keabsahan terhadap akibat yang diperoleh dari pembebanan/pembuatan akta fidusia tersebut, akan bergantung (dependent) pada keabsahan kuasanya. Sehingga apabila kreditor membebani/membuat akta fidusia melalui SKMF di bawah tangan, maka akan membawa konsekuensi dapat tidak diperolehnya hak-hak istimewa sebagaimana yang telah dijanjikan oleh undang- undang kepada kreditor pemegang sertifikat fidusia.

\section{Daftar Pustaka}

J. satrio, Hukum Perikatan, Perikatan yang lahir dari Perjanjian Buku I, Cetakan II, Bandung :PT Citra Aditya Bhakti,2001.

Mariam Darus Badrulzaman, Aneka Hukum Bisnis, Bandung: Alumni, 2005.

Mariam Darus Badrulzaman, Sistem Hukum benda Nasional. Bandung: Alumni,1994.

Satjipto Rahardjo, Ilmu Hukum, Bandung, PT.Citra Aditya Bhakti, 2014.

Sudikno Mertokusumo, Mengenal Hukum Suatu Pengantar, Cetakan III, Yogykarta:Liberty, 2007.

Sudikno metrokusumo, Penemuan Hukum Sebuah Pengantar, Edisi revisi, Yogyakarta:Cahaya Atma Pustaka, 2014.

http://www.hukumonline.com/klinik/detail/lt4c6cdcb7c88c7/surat-kuasa-fidusia-dibawah-tangan, diakses 22 Maret 2016. 